\title{
Offer and Acceptance and the Dynamics of Negotiations: Arguments for Contract Theory from Negotiation Studies
}

\author{
Ekaterina Pannebakker*
}

\begin{abstract}
The doctrine of offer and acceptance forms the basis of the rules of contract formation in most western legal systems. However, if parties enter into elaborate negotiations, these rules may become difficult to apply. This paper addresses the application of the doctrine of offer and acceptance to the formation of contract in the context of negotiations. The paper argues that while the doctrine of offer and acceptance is designed to assess the issues related to the substance of the future eventual contract (the substantive constituent of negotiations), these issues overlap within the context of negotiations with the strategic and tactical behaviour of the negotiators (dynamic constituent of negotiations). Analysis of these two constituents can be found in negotiation studies, a field which has developed over the last decades. Using the rules of offer and acceptance of the UNIDROIT Principles of International Commercial Contracts as an example, this paper shows that the demarcation between the substantive and the dynamic constituents of negotiations can be used as the criterion to distinguish between, on the one hand, the documents and conduct forming a contract, and, on the other hand, other precontractual documents and conduct. Furthermore, the paper discusses the possibility of using the structure of negotiation described by negotiation studies as an additional tool in the usual analysis of facts in order to assess the existence of a contract and the moment of contract formation.
\end{abstract}

Keywords: Contract Formation, Offer and Acceptance, Negotiation, Precontractual, UNIDROIT Principles of International Commercial Contracts

\section{Introduction}

The doctrine of offer and acceptance has proved to be a viable and flexible tool to assess contract formation. This doctrine forms the basis of the rules on contract

* PhD candidate, Erasmus School of Law, Erasmus University Rotterdam. I thank Sanne Taekema and Xandra Kramer for their valuable comments on the draft of this article, and the peer reviewers for their suggestions. The usual disclaimer applies. formation in most legal systems ${ }^{1}$ and is part of the soft law harmonised at the international and European level, including the UNIDROIT Principles of International Commercial Contracts (UNIDROIT Principles), ${ }^{2}$ the Principles of European Contract Law (PECL) ${ }^{3}$ and the Draft Common Frame of Reference (DCFR) ${ }^{4}$ Since the nineteenth century when this doctrine was formulated, 5 it has been adapted to the changes in contracting practices, for example, the conclusion of contracts online ${ }^{6}$ and to the new tendencies in law, for example, the increasing importance of consumer protection (namely, the extension of the ability of a consumer to recall its consent). ${ }^{7}$ This article deals with one of the trends of modern commercial contracting practices, namely, the formation of contract in negotiations and examines, in particular, the implications of this practice for the doctrine of offer and acceptance.

Modern transactions often require long and elaborate negotiations because contractual relationships are

1. R.B. Schlesinger, 'Introduction', in R.B. Schlesinger (ed.), Formation of Contracts: A Study of the Common Core of Legal Systems (1968) 1, at 74; F. Ferrari, 'Offer and Acceptance Inter Absentes', in J.M. Smits (ed.), Elgar Encyclopedia of Comparative Law, 2nd ed. (2012) 625, at $625 \mathrm{ff}$;; K. Zweigert and H. Kötz, Introduction to Comparative Law, translated from the German by Tony Weir, 3rd ed. (1998), at $356 \mathrm{ff}$.

2. Art. 2.1.1 and generally Chapter 2 Sec. 1 UNIDROIT Principles of International Commercial Contracts 2010, <http:// www .unidroit .org/ english/ principles/ contracts/ principles2010/ blackletter2010 -english .pdf> (last visited 17 June 2013). See also Part II (Contract Formation) of the United Nations Convention on Contracts for the International Sale of Goods (CISG), 11 April 1980.

3. Chapter 2 Sec. 2 of the Principles of European Contract Law. O. Lando and H. Beale (eds.), The Principles of European Contract law, Parts I and II. Prepared by the Commission on European Contract Law (1999).

4. Chapter $4 \mathrm{Sec} .2$ of the Draft Common Frame of Reference. Study Group on a European Civil Code/Research Group on EC Private Law (Acquis Group) (eds.), Principles, Definitions and Model Rules of European Private Law. Draft Common Frame of Reference (DCFR), Outline Edition (2009), <http:// ec .europa .eu/ justice/ policies/ civil/ docs/ dcfr_ outline_edition_en.pdf> (last visited 17 June 2013).

5. See for the civil law countries R.J. Pothier, A Treatise on the Law of Obligations, or Contracts (1806), for the common law countries Payne v. Cave (1789) 3 Term Rep. 148, 100 E.R. 502. For the historical roots in Roman law, see R. Zimmermann, The Law of Obligations: Roman Foundations of the Civilian Tradition (1996), at $560 \mathrm{ff}$.

6. D. Nolan, 'Offer and Acceptance in the Electronic Age', in A. Burrows and E. Peel (eds.), Contract Formation and Parties (2010) 61, at 61; M. Furmston and G.J. Tolhurst, Contract Formation: Law and Practice (2010), at 160 and $159 \mathrm{ff}$.

7. E. Cashin Ritaine, 'Nouvelles Tendances en Droit des Obligations - Quel Droit s'Applique?', 13 Uniform Law Review 69, at 87 (2008); G. Howells, 'Consumer Concepts for a European Code?', in R. Schulze (ed.), New Features in Contract Law (2007) 119, at $119 \mathrm{ff}$. 
increasingly sophisticated and only complex negotiations provide a possibility of framing all the details of the possible future agreement. Large-scale construction and development contracts, sale of hi-tech machinery, mergers and acquisitions of companies and joint research agreements in the innovative domains are good illustrations thereof. The 'potential profits' of these contracts are high and the contracts 'have a more lasting effect' on both parties. ${ }^{8}$ In these contracts, the precontractual period - the time between the start of negotiation and the conclusion of the contract - may last several weeks or even several years. During this precontractual period, parties exchange information shaping the future contract. They also exchange some information without the aim of binding themselves to any concrete commitments. Within the context of complex negotiations, it becomes more difficult to determine whether a contract is formed. Furthermore, if a contract is formed, the moment of its formation and the conditions on which it is formed become difficult to define.

The trend towards forming contracts in negotiations is mapped by negotiation studies ${ }^{9}$ that have been conducted in the course of the last thirty years. ${ }^{10}$ These studies have produced insights into the way parties negotiate in practice and on the way one can organise, influence and manage the negotiation process in order to reach a (profitable) agreement. A conscientious approach of the dealmakers to the strategies and tactics of their negotiations is part of commercial practice. Alongside this theoretical understanding, knowledge on negotiations has acquired a practical relevance for the dealmakers who can obtain sophisticated, practice-oriented advice on the way to negotiate deals with the best possible outcome. ${ }^{11}$ Given the difficulties in the assessment of contract formation caused by the tendency towards forming con- tracts by negotiation, negotiation studies should be taken into account by the doctrine of offer and acceptance. ${ }^{12}$ This article aims to assess the way arguments from negotiation studies can help to apply the doctrine of offer and acceptance to the dynamics of negotiations.

To do so, we will first address the doctrine of offer and acceptance, focusing on the rules of the UNIDROIT Principles and explaining this focus in Part 2. Then, the formation of contract according to negotiation studies will be discussed in Part 3. Finally, an inquiry into the implications of negotiation studies for the doctrine of offer and acceptance will be made in Part 4. The inquiry in Part 4 will be structured around the questions of the coming about of the contract (its actual existence) and defining the moment of contract formation.

Before addressing these questions, a preliminary note regarding the scope of this article should be made. This article does not address the concrete rules of offer and acceptance in different countries, but examines the offer and acceptance doctrine in the abstract and takes the rules of the UNIDROIT Principles as a concrete example (for the reasons explained in Section 2.2). The choice of the UNIDROIT Principles as reference makes the discussion primarily relevant for the formation of international commercial contracts. ${ }^{13}$ Furthermore, this article adopts the perspective of contract law and discusses only contract formation, whereas contract validity (e.g. parties' capacity to form a contract, vitiated consent), the question of the 'battle of forms', ${ }^{14}$ and the discussion about liability for negotiations when the contract fails to materialise, fall outside the scope of the article. This choice is made because including these questions would require a much broader inquiry and would not help to explain the relevance of negotiation studies for offer and acceptance generally.
8. B.P. Shapiro and R.S. Posner, 'Making the Major Sale', 84 Harvard Business Review 140, at 140 (2006).

9. Negotiation studies represent an interdisciplinary field of studies, using the methods of social psychology, economics and management science. D. Druckman, 'Frameworks, Cases, and Risk: Dupont's Legacy', in A. Colson (ed.), Entrer en Négociation. Mélanges en I'Honneur de Christophe Dupont (2011) 141, at 142. See also C. Dupont, La Négociation. Conduite, Théorie, Applications, 3rd ed. (1990), at 289; S.E. Weiss, 'International Business Negotiation in a Globalizing World: Reflections on the Contributions and Future of a (Sub)Field', 11 International Negotiation 287 (2006).

10. From the considerable literature, see Dupont (1990), above n. 9; D.A. Lax and J.K. Sebenius, 3-D Negotiation: Powerful Tools to Change the Game in Your Most Important Deals (2006); Weiss, above n. 9; C. Dupont, La Négociation Post-moderne, Bilan des Connaissances, Acquis et Lacunes, Perspectives (2006); R. Mnookin, Bargaining with the Devil: When to Negotiate and when to Fight (2010); A. Lempereur and A. Colson, Méthode de Négociation, 2nd ed. (2010); R. Lewicki, B. Barry \& D. Saunders, Negotiation, 6th ed. (2010) with further references.

11. See inter alia R. Fisher, W. Ury \& B. Patton, Getting to Yes: Negotiating an Agreement Without Giving In, 3rd ed. (2011). See also practically orientated projects of the Program on Negotiation (PON) at Harvard Law School, <http:// www .pon .harvard .edu/about/ > (last visited 14 Oct. 2013); 'Clingendael' Netherlands Institute of International Relations, <www.clingendael.nl> (last visited 14 Oct. 2013); ESSEC IRÉNÉ (Institut de Recherche et de I'Enseignement sur la Négociation), <http://irene.essec.edu/> (last visited 17 June 2013).
12. This hypothesis is based upon two assumptions: first, that contract law is closely connected with the realities it regulates, and second, that the knowledge on negotiation reported in negotiation studies reflects the empirical reality of negotiation. See generally with further references W.H. van Boom, I. Giesen \& A.J. Verheij (eds.), Gedrag en Privaatrecht: Over Gedragspresumpties en Gedragseffecten bij Privaatrechtelijke Leerstukken (2008); B. van Klink and S. Taekema 'On the Border: Limits and Possibilities of Interdisciplinary Research', in B. van Klink and S. Taekema (eds.), Law and Method: Interdisciplinary Research into Law (2011). See also n. 9 above for the characterisation of negotiation studies.

13. On the scope see the Preamble of the UNIDROIT Principles. The level of abstraction of this paper is general legal theory, and references are primarily made to the UNIDROIT Principles. Civil law and (English) common law systems are, however, distinguished in Sec. 4.3., discussing the diverging assumptions about negotiation process that underpin the law in these systems.

14. On the definition of the 'battle of forms', see inter alia U. Magnus, 'Last Shot vs. Knock Out: Still Battle over the Battle of Forms under the CISG', in R. Cranston, J. Ramberg \& J. Ziegel (eds.), Commercial Law Challenges in the 21st Century: Jan Hellner in Memoriam (2007) 185, at $185 \mathrm{ff}$.; G. Dannemann, "The "Battle of the Forms" and the Conflict of Laws', in F.D. Rose (ed.), Lex Mercatoria: Essays on International Commercial Law in Honour of Francis Reynolds (2000) 199, at $199 \mathrm{ff}$. 


\section{The Doctrine of Offer and Acceptance}

This part will present the core of the doctrine of offer and acceptance (Section 2.1) and provide a background for a conceptual discussion of this doctrine on the basis of the rules on contract formation of the UNIDROIT Principles (Section 2.2).

\subsection{The Substance of the Doctrine of Offer and Acceptance}

The rules of offer and acceptance draw the line between 'what is and what is not a contract'15 and delimit the contract from any other relationship. According to these rules, in order to form a contract an offeror has to make a proposal - an offer - to perform an act (or to abstain from acting) to the offeree, and the offeree has to accept this offer. ${ }^{16}$ The moment of contract formation is the precise time at which an offer established by an offeror with a sufficient level of certainty and completeness is accepted by an offeree. ${ }^{17}$ These rules are designed to answer the questions as to whether a contract is formed and at which moment it is formed. Furthermore, this doctrine designates the way to assess the conditions on which a contract is formed. This is done by defining the acts that qualify as offer, acceptance, sending and receipt of each of these. ${ }^{18}$ Stated in this way, these rules are common to several legal systems and form the doctrine of offer and acceptance within the theory of contract law.

However, further and more concrete content of the offer and acceptance rules varies in different legal systems. ${ }^{19}$, ${ }^{20}$ For instance, different legal systems resolve the questions of what qualifies as an offer, whether or not an offer can be revoked and what qualifies as acceptance in different ways. $^{21}$ Seen in a comparative perspective, these differences limit the possibilities of analysing this doctrine in abstracto. A general discussion of the doctrine of offer and acceptance is therefore possible only if one moves away from concrete legal systems ${ }^{22}$ and looks at the example of the rules of contract formation accepted generally in most legal systems. The UNIDROIT

15. S.A. Smith, Contract Theory (2004), at 168

16. Ferrari, above n. 1, at 625 ff.; E.A. Farnsworth, 'Comparative Contract Law', in M. Reimann and R. Zimmermann (eds.), The Oxford Handbook of Comparative Law (2006) 899, at 915 ff.; Schlesinger (ed.), above n. 2, at 1-177.

17. Ferrari, above n. 1, at 625 ff.; Farnsworth, above n. 16, at 915 ff.; R. Schlesinger, above n. 2.

18. A.T. von Mehren, 'The Comparative Study of Law', 6/7 Tulane Civil Law Forum 43, at 54 (1991-1992).

19. Ferrari, above n. 1; Schlesinger, above n. 1; Furmston and Tolhurst, above n. 6 , at 2 .

20. For example, the exact point in time when the offer is considered to be accepted is based on different principles, namely the principles of 'information', 'reception', 'expedition' and 'declaration'. See for an overview Ferrari, above n. 1, at $625 \mathrm{ff}$

21. Von Mehren, above n. 18 , at 54

22. Such a transnational approach, 'without differentiating between common law and civil law' systems is possible from the point of view of contract theory. See Smith, above n. 15, at viii-ix.
Principles are an appropriate reference for this purpose for a number of reasons. They represent a restatement ${ }^{23}$ of national approaches in different countries with a world-wide territorial scope, ${ }^{24}$ and they are formulated as a harmonised instrument as a result of considerable research and debate. ${ }^{25}$ Furthermore, the UNIDROIT Principles are used not only as an academic reference and a source of inspiration for legislators in various countries ${ }^{26}$ but also as a persuasive authority for international arbitrators, national courts and drafters of international contracts ${ }^{27}$ as a choice of a neutral nonstate law. ${ }^{28}$

\subsection{Offer and Acceptance in the UNIDROIT Principles}

The rules on offer and acceptance in the UNIDROIT Principles rely on the core of the doctrine described above, but are broader. According to the UNIDROIT Principles, 'A contract may be concluded either by the acceptance of an offer or by conduct of the parties that is sufficient to shom agreement. ${ }^{, 29}$ The reliance on the 'traditional mechanism, ${ }^{30}$ of offer and acceptance as the main tool of analysis of contract formation is underlined by the drafters of the UNIDROIT Principles in the official comments. ${ }^{31}$ The UNIDROIT Principles' rules include all three questions of offer and acceptance doctrine (the offer, the acceptance and the moment of their meeting). Additionally, the rules state that other behaviour (or 'conduct') demonstrating an agreement of the parties may qualify as formation of a contract. The main rule on contract formation extends therefore to cases that are

23. On this concept, see N. Jansen, The Making of Legal Authority: Nonlegislative Codifications in Historical and Comparative Perspective (2010), at $92 \mathrm{ff}$.

24. M.J. Bonell and R. Peleggi, 'Unidroit Principles of International Commercial Contracts and Draft Common Frame of Reference: A Synoptical Table', 14 Uniform Law Review 437, at 450-451 (2009).

25. S. Vogenauer, 'Introduction', in S. Vogenauer and J. Kleinheisterkamp (eds.), Commentary on the UNIDROIT Principles of International Commercial Contracts (PICC) (2009) 1, at 9

26. S. Lake, 'An Empirical Study of the UNIDROIT Principles - International and British Responses', 16 Uniform Law Review 669, at 696 ff. (2011). See also inter alia T. Uchida 'Contract Law Reform in Japan and the UNIDROIT Principles', 16 Uniform Law Review 705, at 710 ff. (2011); E. Cashin Ritaine and E. Lein (eds.), The UNIDROIT Principles 2004: Their Impact on Contractual Practice, Jurisprudence and Codification. Reports of the ISDC Colloquium (8/9 June 2006) (2007).

27. Lake, above n. 26, at 702; K.P. Berger, The Creeping Codification of the New Lex Mercatoria (2010), at 202; M.J. Bonell, 'The UNIDROIT Principles a Decade After their Appearance: What Have They Achieved and What Are Their Prospects for the Future?', in Cashin Ritaine and Lein (eds.), above n. 26, 259, at $259 \mathrm{ff}$.

28. The question as to whether parties can validly choose lex mercatoria generally, and the UNIDROIT Principles particularly, as the law applicable to their international contract has been the subject of academic debate. For an overview of the debate, see O. Lando 'Some Features of The Law of Contract in the Third Millennium', Scandinavian Studies in Law (2000) 343, at 369 ff., <http://www.scandinavianlaw.se/pdf/40 -13.pdf> (last visited 17 June 2013). It is currently undisputed that a choice for UNIDROIT as applicable law is valid, if the dispute is subject to arbitration. See Cashin Ritaine, above n. 7, at 95.

29. Art. 2.1.1 UNIDROIT Principles.

30. Vogenauer, in Vogenauer and Kleinheisterkamp (eds.), above n. 25, at

31. Official Comments to Art. 2.1.1 UNIDROIT Principles, <http:// www unilex.info> (last visited 17 June 2013). 
more complicated than a simple acceptance of an offer, namely, to cases where a meeting of parties' wills is in place, but the analysis of their meeting through offer and acceptance might be excessively fictional. This is the case of formation of a multiparty contract, ${ }^{32}$ formation of contract by conduct, ${ }^{33}$ formation of contract by simultaneous execution, ${ }^{34}$ and contracts formed in negotiations. ${ }^{35}$ The choice of formulation in the UNIDROIT Principles is primarily motivated by the 'special needs of international commerce' 36 and by the 'basic underlying idea of freedom of contract'. ${ }^{37}$ Furthermore, the commentators characterise the UNIDROIT Principles as 'modern and innovative" 38 and state that the "traditional mechanism' ${ }^{39}$ of offer and acceptance 'does not necessarily have to apply in the world of international commercial contracts. ${ }^{40}$ The Articles of Chapter 2 (Formation and authority of agents) of the UNIDROIT Principles are designed primarily for the 'traditional mechanism' of offer and acceptance, while Articles 2.1.12-2.1.18 provide the possibility to form contract by conduct. $^{41}$

The offer is defined in the UNIDROIT Principles as ' $a$ proposal for concluding a contract'; 42 the offer should be 'sufficiently definite and indicate the intention of the offeror to be bound in case of acceptance'. ${ }^{43}$ The acceptance is defined as an avail of this opportunity: 'a statement made by or other conduct of the offeree indicating assent to an offer is an acceptance'. ${ }^{44}$

To summarise, in a relationship which can lead to the formation of a contract, either (1) an offer, an acceptance and a moment of their meeting can be identified or (2) other behaviour (conduct) of parties indicating the end of the negotiation and the beginning of a contractual relationship should be in place. If the parties are involved in complex negotiations, the application of these elements of the doctrine of offer and acceptance raises the question as to the method of defining which

32. See Furmston and Tolhurst, above n. 6, at 12, invoking the ratio of the decision in an English case Clarke v. Dunraven [1897] AC 59.

33. See also M.M. Siems, "“Unevenly Formed Contracts": Ignoring the "Mirror of Offer and Acceptance"', 12 European Review of Private Law 771, at 771 ff. (2004). Discussing contracts formed by conduct, Siems refers to contracts open to more than one party, face to face contracts, joint signature contracts, contracts formed by conduct and contracts formed by written declaration, calling them 'unevenly formed contracts'

34. Kleinheisterkamp, in Vogenauer and Kleinheisterkamp (eds.), above n. 25 , at 220

35. Id., at 221 .

36. Vogenauer, in Vogenauer and Kleinheisterkamp (eds.), above n. 25, at 15.

37. Id.

38. Id.

39. Id.

40. Id.

41. Kleinheisterkamp, in Vogenauer and Kleinheisterkamp (eds.), above $n$ 25, at 218. Compare A.K. Schnyder and R.M. Straub, 'The Conclusion of a Contract in Accordance with UNIDROIT Principles', 1 European Journal of Law Reform 243, (1999), arguing that all the Articles of the UNIDROIT Principles are designed only for a consecutive way of contract formation.

42. Art. 2.1.2 UNIDROIT Principles.

43. Id.

44. Art. 2.1.6(1) UNIDROIT Principles conduct is sufficient to show agreement, be it detecting the offer and acceptance in negotiation or identifying a relevant conduct. Before trying to answer these questions in Part 4, we will look more closely at the process of formation of contract in negotiation in the next part.

\section{The Formation of Contract According to Negotiation Studies}

We shall elaborate further on the formation of contract according to negotiation studies, addressing in particular the strategies and tactics used in negotiations and the distinction between the integrative and distributive types of negotiation (Section 3.1), and describe the substantive and dynamic constituents of negotiations (Section 3.2).

\subsection{Strategies and Tactics of Integrative and Distributive Negotiations}

Negotiation studies ${ }^{45}$ analyse the process of coming to an agreement primarily in terms of strategies and tactics. The term negotiation means an interaction of two or more actors faced simultaneously with divergences and interdependences and voluntarily looking for a mutually acceptable solution that allows them to create, maintain or develop a relationship. ${ }^{46}$ Negotiations are analysed as an activity whereby participants with diverging interests search for agreement despite a difference in their points of view. This search for agreement is analysed in terms of strategy, 'the overall plan to accomplish one's goal in a negotiation', and tactics, the 'short-term, adaptive moves designed to enact or pursue broad (or higher-level) strategies'. ${ }^{47}$ Depending on the strategy and tactics used by the parties, most researchers distinguish two main types of negotiations: the 'integrative' and the 'distributive' type. ${ }^{48}$ This distinction is widely accepted despite the absence of unanimity in approaches to negotiations. ${ }^{49}$ Integrative negotiations are characterised as a

45. See above n. 9.

46. '[L]a négociation est une activité qui met face à face deux ou plusieurs acteurs qui, confrontés à la fois à des divergences et à des interdépendances, choisissent (ou trouvent opportun) de rechercher volontairement une solution mutuellement acceptable qui leur permet de créer, maintenir ou développer (ne fût-ce que temporairement) une relation'. See Dupont (1990), above n. 9, at 11. For an overview of other definitions, see M. Kaplan, Commercieel Onderhandelen: Een Transdisciplinaire Aanpak. Doctoral thesis Leiden University (2010), at 13-43, $<$ https://openaccess.leidenuniv.nl/handle/1887/16231> (last visited 17 June 2013).

47. Lewicki, Barry \& Saunders, above n. 10, at 110-111.

48. R.E. Walton and R.B. McKersie, A Behavioral Theory of Labor Negotiations. An Analysis of Social Interaction System (1965), at 4-5. Walton and McKersie use the terms 'integrative' and 'distributive' 'bargaining' which correspond to a large extent to the 'cooperative' and 'conflict' negotiation and to the 'integrative' and 'distributive' 'dimension' of negotiation respectively in the terms used by other authors. See Dupont (2006), above n. 10, at 32-33.

49. For an overview of the approaches to negotiation, see Dupont (2006), above n. 10, at 99-112. 
search for agreement between non-conflicting parties, while distributive negotiations suppose that parties' interests are conflicting.

More concretely, in the integrative negotiation, the interests of the parties are complementary or not conflicting, negotiations are driven by the parties' common goal. ${ }^{50}$ One party is willing to believe that the other's interests are valid, and both parties make it explicit by their behaviour and act accordingly. ${ }^{51}$ For example, promising is named amongst the tactics of integrative negotiations. ${ }^{52}$ Furthermore, the integrative approach is often characterised by negotiating over a long period of time because the tactics of integrative negotiation are said to be more successful when the parties have some time between the negotiation itself and the supposed start of implementation of the outcome of this negotiation (for example, the time between the start of negotiation and the start of execution of a contract). ${ }^{53}$ General$\mathrm{ly}$, the tactics of integrative negotiation presume a certain level of cooperation between the parties and an extended exchange of information about the priorities and preferences of each party.

By contrast, in distributive negotiation the interests of the negotiating parties are usually conflicting. The tactics of distributive negotiation are to a certain extent aggressive. An example of a distributive tactic is the public disclosure. Making public the information about the development of negotiations makes third parties immediately aware of a possible agreement to come. ${ }^{54}$ This tactic may have the effect of putting the other party under pressure to conclude an agreement that has been publicly announced. Another example of a distributive tactic is the tactic of commitment. This tactic consists in expressing a negotiation position, containing an explicit pledge on future actions, such as, for example, the following statement: 'if you do not agree on this position, we shall not continue the negotiation any further'. Commitment is usually considered by negotiators as a threat; it may indeed be one, but most often it is a means to explicitly clarify the negotiator's position. ${ }^{55}$

A combination of integrative and distributive negotiation is also possible. This combination would, however, represent only a change in the cooperative and distributive episodes of the entire negotiation, while the entire negotiation process in question would still be characterised by only one type. ${ }^{56}$ The decisive characteristic allowing a classification of a concrete negotiation as one or the other type is the intention of the parties. ${ }^{57}$ If the

50. Lewicki, Barry \& Saunders, above n. 10, at 9. See also C. Smets-Gary and $\mathrm{M}$. Becker, Médiation et Techniques de Négociation Intégrative. Approche Pratique en Matière Civile, Commerciale et Sociale (2011).

51. Lewicki, Barry \& Saunders, above n. 10, at 105.

52. T.C. Schelling, Strategies of Commitment and Other Essays (2006), at 9 $\mathrm{ff}$.

53. This is a conclusion of a research made in 2006. See for references Lewicki, Barry \& Saunders, above n. 10, at 104.

54. Lewicki, Barry \& Saunders, above n. 10 , at 56

55. Id.

56. C. Dupont, 'Coopérer Pour s'Entendre ou s'Affronter', in A. Colson (ed.), above n. 9,39 , at 48

57. Id. initial intention of the parties is coming to an agreement 'because of the situation', ${ }^{58}$ or because of the person with whom a negotiation is conducted, ${ }^{59}$ then even if the negotiation becomes distributive, it would be easy to go back to the integrative approach after a distributive period. For example, the entire negotiation may be characterised as integrative if parties face an issue that cannot be resolved during an initially integrative negotiation, then turn to an expert or a mediator or an internally contractually appointed dispute board (and this might be a distributive period) and thereafter come back to the discussion (thus, come back to the integrative approach). ${ }^{60}$

Strategies, tactics and the patterns of integrative and distributive negotiations characterise the process of searching for agreement. The analysis of negotiations in terms of strategies and tactics answers the question as to 'how' the parties come to an agreement, allowing a general characteristic to be given to the process of negotiations. Alongside this characteristic of the negotiation process, negotiation studies have identified the patterns of issues, which are negotiated. These issues answer the question as to 'what' is negotiated. The next section will be dedicated to the elaboration of this characteristic of negotiations.

\subsection{The Substantive and the Dynamic} Constituents of Negotiation

According to negotiation studies, negotiation is characterised by two different constituents: the substantive constituent that is directly related to the content of contracts and the dynamic constituent related only to the management of the negotiations.

In order to sketch the substantive constituent, negotiation studies emphasise that negotiations always arise in connection with a product, a service, or a concrete change of the current situation desired by the parties. ${ }^{61}$ The parameters of this service, product or change of a concrete situation are the end result of these negotiations. These parameters represent the substantive constituent of negotiations (also called its technical, objective or economic constituent). ${ }^{62}$ This constituent embraces, therefore, all the issues related to the end result of negotiations, including the questions of price, quality, deadlines of a service or milestones of a project, payment conditions, guaranties and other conditions of the product or service. These characteristics of the future product or service are the issues that usually represent the content of the future eventual contract.

Simultaneously to the substantive constituent, negotiations include the second constituent of negotiations, the dynamic constituent (also called 'relational' constituent) ${ }^{63}$ It embraces the processes separated from the core and content of the future contract. The dynamic con-

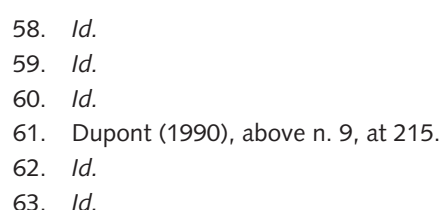


stituent includes, for instance, planning, timing and structuring of the negotiations, as well as the distribution of tasks if any is necessary during the negotiations. These issues are not the same as the issues included in the eventual final contract. However, the issues forming the dynamic constituent are relevant for the management of the negotiation process within the context of a business deal.

Negotiation studies detail the content and the relevance of these issues for the management of negotiations as follows. Firstly, the timing and structuring of negotiations - 'What is the time period of the negotiation? If negotiators expect long, protracted deliberations, they might want to negotiate the time and duration of the sessions. When do we start? How long do we meet? When do we need to end? What will happen if we deadlock? ${ }^{64} \mathrm{Sec}-$ ondly, the formalisation of the development of negotiation. 'How will we keep track of what is agreed to?' 65 Track is kept, for instance, through intermediary documents, such as time schedules, letters, protocols, memoranda and other similar documents. These documents become particularly relevant since '[i]n large scale negotiations, process and outcome are intertwined and recurring, not single iterations. ${ }^{66}$ Furthermore, negotiation studies suggest that if an agreement is complex, it would most probably be 'reviewed by experts and specialists - attorneys, financial analysts, accountants, engineers, and so on. ${ }^{67}$ Implicitly confirming the distinction between the technical and the dynamic constituent of negotiations, it is usually important for negotiators that 'discussions about these dynamic issues should occur before the major substantive issues are raised' in order to allow time for the proper working out of the eventual agreement. The dynamic constituent is therefore the 'environment' of the transaction and the field where the negotiations are managed by the parties by using strategies, tactics, timing and structuring of the negotiation process.

Within the dynamic constituent, the process of managing negotiation has, according to negotiation studies, a pertinent internal structure. It consists of the following elements: (1) a systematic research of information; (2) selection of the product and counterpart; (3) planning; (4) calculating advantages of the transaction; (5) preparation of one or several positions by the parties; (6) appointing the entrusted negotiator(s) in charge; (7) thereafter, research of an agreement though successive signals and through a more or less formal form, - letters of intent, protocols et cetera and (8) organisation of the follow-up of the relationship. ${ }^{68}$

Having sketched the doctrine of offer and acceptance as well as the process of contract formation through the lens of negotiation studies in Parts 2 and 3, an attempt will be made in Part 4 to combine these two views in order to assess whether knowledge from negotiation

64. Lewicki, Barry \& Saunders, above n. 10, at 136.

65. Id.

66. Weiss, above n. 9, at 307; Shapiro and Posner, above n. 8.

67. Lewicki, Barry \& Saunders, above n. 10, at 136.

68. Shapiro and Posner, above n. 8, at 140. studies can shed light on the application of the doctrine of offer and acceptance to the situations when the contract is formed in negotiations.

\section{Applying the Doctrine of Offer and Acceptance to the Dynamics of Negotiation}

The main implication of the dynamics of the negotiations for the application of the doctrine of offer and acceptance is the difficulty to distinguish the elements forming the contract (offer and acceptance, or a conduct sufficient to show agreement). As a matter of fact, the doctrine of offer and acceptance has been criticised in legal scholarship for its static character (Section 4.1). In the light of this critique, we shall address further how the characteristics of negotiations defined in negotiation studies can be used in the legal analysis to help to identify whether a contract is formed (Section 4.2) and distinguishing the moment of contract formation (Section 4.3).

\subsection{The Existing Critique of the Offer and} Acceptance Rules

The doctrine of offer and acceptance has been criticised in legal theory for failing to take into account the dynamics of the process whereby the contract comes into existence. This critique can be found in contemporary scholarship, for instance, in the works of Atiyah, and traced back to earlier contract theories of the years 1970-1980, including the works of Macneil, Gilmore and Feinman.

More concretely, in terms used by Atiyah, ${ }^{69}$ the doctrine of offer and acceptance still perceives complex transactions as simple dealings. It therefore fails to take into account the process whereby parties shape their agreements. ${ }^{70}$ Consequently, if a contract is formed in negotiations, the courts often 'reason backwards', ${ }^{71}$ declaring that a contract exists, and then look for 'something that resembles offer and acceptance. ${ }^{, 72}$ This critique of the offer and acceptance rules emphasises their static character. It stresses as well that this doctrine fails to take into account the dynamics of negotiations and the futurity in the assessment of contract formation. Within the context of formation of a complex agreement, the notion of futurity corresponds to the planning

69. This type of critique pertains generally to the 'contract-as-tort' theorists. They emphasise the growing role of tort in relations traditionally classified within the law of obligations as contract. See P.S. Atiyah, The Rise and Fall of Freedom of Contract (1979); G. Gilmore, The Death of Contract, 2nd ed. (1995)

70. P.S. Atiyah, An Introduction to the Law of Contracts, 6 th ed. (2005), at 74, 137, and 208.

71. Smith, above n. 15, at 176 .

72. Id. This is mostly Anglo-American scholarship that provides this relatively detailed critique of the offer and acceptance rules. For a synthesis of critical remarks in continental scholarship, see M. Fontaine (ed.), Le Processus de Formation du Contrat: Contributions Comparatives et Interdisciplinaires à l'Harmonisation du Droit Européen (2002). 
of relationships and their adaptation to changing circumstances.

The futurity of the process whereby parties come to agreements has also been emphasised in earlier legal scholarship. In particular, Macneil called the back and forth of opinions and progressive development of the parties' relationship during contract formation a 'relational' aspect of contract. ${ }^{73} \mathrm{He}$ argued that contract law should have different (varying) rules depending on the degree to which the relational aspect is present in a contract. In order to do so, he suggested using a framework of 'norms' for analysing contract. ${ }^{74}$ Feinman has pointed as well to the need for classical contract law to accommodate the modern transactions by providing a 'framework for parties who engage in business planning'. 75 This framework would allow parties 'to create relations, to determine their content, to avoid them altogether. ${ }^{76}$ It is to be noted, however, that Macneil's and Feinman's theories have come under criticism themselves. In particular, Macneil's views have been perhaps most criticised for not having proposed rules that would be predictable and certain enough to replace the doctrines currently used. ${ }^{77}$

However, the critiques of the offer and acceptance rules have acquired considerable influence, ${ }^{78}$ and their claim that contract law should take account of the process whereby parties come to an agreement remains valid. These claims are echoed by the commentators of the UNIDROIT Principles, particularly in the explanation of the reasons why the UNIDROIT Principles provide a rule about the formation of contract by conduct. ${ }^{79}$ Yet in order to apply this rule and distinguish a contract in the conduct of the parties, one still needs to address whether conduct in a concrete situation leads to forma-

73. Macneil elaborated a theory called 'relational' theory of contract. It embraces both the formation and the execution of contracts. See a selection of works by Macneil in D. Campbell (ed.), The Relational Theory of Contract: Selected Works of lan Macneil (2001).

74. These norms are 'role integrity'; 'reciprocity'; 'implementation and planning'; 'effectuation of consent'; ' flexibility'; 'contractual solidarity'; 'restitution, reliance and expectation interests'; 'creation and restraint of power'; 'propriety of means'; 'harmonisation with the social matrix' and the 'relational' norms 'preservation of the relation' and 'harmonisation of relational conflict'. See D. Campbell (ed.), The Relational Theory of Contract: Selected Works of lan Macneil (2001), at 163-167.

75. This type of critique is sometimes referred to as 'neo-classical' contract theory, primarily relevant for the U.S. law. See J.M. Feinman, 'The Significance of Contract Theory', 58 University of Cincinnati Law Review 1283, at $1285 \mathrm{ff}$. (1990).

76. Feinman, above, n. 75, at 1288. See also D.K. Hart, 'Contract Formation and the Entrenchment of Power', 41 Loyola University of Chicago Law Journal 175 (2009).

77. See for an overview of the critique (including Collins, Eisenberg, Posner) P. Vincent-Jones 'The Reception of Ian Macneil's Work on Contracts in the UK', in D. Campbell (ed.), The Relational Theory of Contract: Selected Works of lan Macneil (2001) 67, at 67-86. See also C. Mitchell, 'Narrativising Contract Law', 29 Legal Studies 19, at 21-22 (2009).

78. As Macneil himself contends, concluding on a resonance that the relational contract theory created in the legal thought: 'We are all relationists now, but not when it comes to law.' See I. Macneil 'Relational Contract Theory: Challenges and Queries', in Campbell (ed.), above n. 74 at 383-384.

79. Chapter 2 (Formation and authority of agents) UNIDROIT Principles, especially Arts. 2.1.12-2.1.18. See also Sec. 2.2. of this paper. tion of a contract. At the same time, both the existing critique of the doctrine of offer and acceptance and the provisions of the UNIDROIT Principles point to the relevance of knowledge about the process of negotiations in contracting practice. Room is therefore left in the discussion of the application of the offer and acceptance doctrine to modern transactions for an argument based on negotiation studies.

\subsection{The Existence of the Contract: Delimiting Offer and Acceptance from Other Precontractual Documents}

If one relates the doctrine of offer and acceptance to the distinction between the two constituents of negotiations, this doctrine seems to be designed to assess only the substantive constituent of negotiations. Therefore, identifying the constituent to which a concrete document or conduct in the contract formation refers, may be used as a criterion for deciding whether this represents an element forming a contract.

In order to link up the offer and acceptance rules and the two constituents of negotiation, let us reformulate the critique of the static character of offer and acceptance in the light of negotiation studies. As has been discussed in Section 3.2, the issues pertaining to the substance and content of the future contract represent the substantive constituent of negotiations. Therefore, the criticism of the doctrine of offer and acceptance means in the light of negotiation studies that this doctrine is designed to assess only the substantive constituent of the contract formation, but not its dynamic constituent. However, in the negotiations, the two constituents overlap. For instance, if the process of negotiations is documented, various precontractual documents can be created. These documents can be related to the dynamic constituent only (including the issues related only to the management of negotiations). Alternatively, the documents can combine issues from both the substantive and dynamic constituents (and thus include both the issues concerning the management of negotiations and the agreed conditions of a future contract). This is why, if no distinction between the two constituents is made, the elements of the doctrine of offer and acceptance are easily confused in the context of negotiations with other issues arising at the precontractual stage. If a distinction can be made on the basis of the constituent of negotiation to which a document (or conduct) relates, a conclusion can be made as to whether or not a document should be taken into consideration for the purposes of the offer and acceptance rules. We can draw supporting arguments from envisaging two examples.

The situations where the two constituents do not overlap can be illustrated by the following example. Parties to a negotiation create a document regulating the timing, structuring of their negotiations or mentioning an issue that needs to be solved before agreeing on all the final provisions of a contract. This document does not represent any of the elements forming a contract because it relates only to the dynamic constituent of negotiations and falls outside the scope of the offer and 
acceptance doctrine. Alternatively, a document or conduct may show an agreement about a concrete end result of the negotiations, including the parameters of a service, product or change of a concrete situation. This document or conduct is likely to contain the elements of the doctrine of offer and acceptance because it relates to the substantive constituent of negotiations, and the acts within this constituent can be analysed through the doctrine of offer and acceptance.

Another example illustrates the situations where the substantive and the dynamic constituents overlap. A document containing various precontractual understandings has been analysed in an ICC (International Chamber of Commerce) award, ${ }^{80}$ applying the UNIDROIT Principles. ${ }^{81}$ In this case, a 'Memorandum of Understanding' had been signed by parties during their negotiations. The document contained, on the one hand, obligations related to the sale by one party of vehicles and spare parts to the other party. On the other hand, the document described parties' understandings regarding their future cooperation and organisation of the after-sale services. When a dispute arose, one of the main issues that the arbitral tribunal had to address was the legal status of the Memorandum of Understanding. On the basis of the analysis of this document's text, the arbiters decided that it included two types of conditions. The conditions of the first type represented 'specific conditions ... that are the result of parties' agreements and should therefore be considered as final obligations' ${ }^{82}$ Due to this content, the first type of conditions has been declared binding. By contrast, the second type of conditions represented a 'general description of the parties' intention to enter into certain agreements. ${ }^{83}$ The second type of conditions was held to be not binding on the substance, but representing an obligation for parties to use their 'best efforts' to implement the general agreements into specific terms, on the basis of the Article 5.1.4 UNIDROIT Principles. ${ }^{84}$

The reasoning in this arbitral award implicitly confirms the difference between the substantive and dynamic constituents of the process of contract formation. The award does not directly refer to this difference as a criterion for the delimitation between the two types of conditions in the Memorandum of Understanding in question. Its conditions are classified into, on the one hand, contractual and, on the other hand, other conditions. However, an explicit mention of the reason why the

80. ICC award No. 8331 (1996), published in Journal de Droit International, at 1041-1046 (1998), note Y. Derlains, 2 Bulletin de La Cour Internationale d'Arbitrage de la CCI (1999). See also M. Fontaine and F. De Ly, Drafting International Contracts: An Analysis of Contract Clauses (2006), at 38-39.

81. The provisions of the UNIDROIT Principles 2004 that were applied in this award remain unchanged in the UNIDROIT Principles 2010 discussed in this article.

82. ICC award No. 8331 (1996), above n. 80.

83. Id.

84. This obligation is based on the para. 2 of Art. 5.1.4 UNIDROIT Principles 2004, stating as follows: 'To the extent that an obligation of a party involves a duty of best efforts in the performance of an activity, that party is bound to make such efforts as would be made by a reasonable person of the same kind in the same circumstances'. issues are classified in this way would strengthen the motivation of the decision, for the following reasons. The argument in the award is based on the understanding of the document's text by the arbiters. They analysed the formulation of each condition and decided on this basis, whether it represented a condition of a contract (a binding 'final obligation') or a non-contractual condition. The analysis of the document's text eventually implied an assessment by the arbitral tribunal of the context of negotiations and the entire relationship between the parties. Nonetheless, the award does not specify the concrete way this analysis has been made. By contrast, the flow of the argument in this award can be understood through the distinction between the substantive and dynamic constituents of negotiations. The arbiters' general line of reasoning corresponds to the distinction between these two constituents. The award mentions firstly the conditions that were related to the substance of the contract and corresponded to the substantive constituent. The conditions that were considered as contractual were conditions that could have been assessed through the doctrine of offer and acceptance. Secondly, the award mentions other conditions related to understandings of the parties that did not represent contractual obligations. These conditions might be classified as corresponding to the dynamic constituent because these were forward-looking understandings of the parties shaping their future eventual deals. A reference to this distinction, therefore, could have strengthened the motivation of the decision in this award because it would make explicit the flow of the argument the text analysis.

Hence, the distinction between two types of conditions related to two different constituents of negotiations exists in the legal assessment, albeit implicitly, as appears from the example of the ICC award provided above. Directly relating the conditions of a document to one of the constituents of negotiations can provide a context for its text analysis and an additional tool to make text analysis explicit, strengthening the argument for which this analysis is made, for example, in a motivation of a court decision or arbitral award.

This is, however, not the only reason why the distinction between two constituents matters. A similar distinction between different precontractual documents has been made by Van Dunné. He distinguishes documents related, on the one hand, to the 'procedure' of preparation of the future agreement and, on the other hand, to the 'content' of a future agreement. ${ }^{85}$ Having said this, if the constituent of negotiation to which a document (or conduct) relates is identified, it becomes easier to define whether or not this document or conduct should be taken into consideration for the purposes of offer and acceptance. In the situations where the two constituents overlap, this criterion can help to define which concrete conditions refer to the formation of contract. It appears

85. Van Dunné distinguishes between 'procedurele' and 'inhoudelijke' 'precontractuele regelingen' in Dutch law. See J.M. van Dunné, Verbintenissenrecht (2004), at 238. 
as well that the formation of contract by negotiation can be seen as a dynamic process only if each concrete issue or act within the negotiations is addressed separately, but not on the basis of a static 'all or nothing' model embracing the entire process of negotiations. For example, in the ICC award above, the negotiation process had to be deconstructed into separate conditions. It could not be seen as entire process because its separate parts played different roles in the parties' relationship and had different legal effect. Consequently, for the purposes of the application of the criterion, if a precontractual document combines issues referring to both constituents of negotiations, every negotiated obligation should be isolated and analysed separately from the other issues addressed in this document. In this way, from several documents created at the precontractual stage, conditions can be selected that progressively form a contract (and these conditions can be contained in several precontractual documents).

One further reason for the relevance of this criterion (delimiting the constituent of negotiations) needs to be addressed. This criterion can be applied in order to identify the legal meaning of various precontractual documents. Several types of precontractual documents have been discussed in legal scholarship. It is also known that contracting parties deliberately give names to their precontractual documents, without always being consistent. ${ }^{86}$ Therefore, the legal effect of these documents is usually defined on a case-by-case basis by analysing their text. Moreover, it can be difficult to classify these documents in one of the traditional legal categories. A precontractual document can represent an offer or an acceptance ${ }^{87}$ or just a gentleman's agreement (an agreement which creates obligations in honour, but not in law). ${ }^{88}$ It can be an invitation to start negotiations (a document asking to begin negotiations or to make an offer), ${ }^{89}$ a letter of intent (a general name for various documents stating preliminary understandings of parties regarding a future contract) ${ }^{90}$ or other. ${ }^{91}$ Relating these types of documents to the dynamics of negotiations described by negotiation studies suggests that these documents often relate only to the dynamic constituent of negotiation because they represent an envi-

86. See for an overview of the documents addressed in scholarship and the names: International Chamber of Commerce (ed.), Formation of Contracts and Precontractual Liability (1993).

87. Furmston and Tolhurst, above n. 6, at 201 ff.; P. Blanchard, 'Offer and Acceptance in International Contract Negotiation. A Comparative Study', 1 International Business Law Journal 3 (2008); Fontaine and De Ly, above n. 80, at $20 \mathrm{ff}$.; See also R.B. Lake and U. Draetta, Letters of Intent and other Precontractual Documents: Comparative Analysis and Forms, 2nd ed. (1994).

88. See inter alia B. Wessels, Letter of Intent (2010), at 16-17; F.W. Grosheide, 'The Gentleman's Agreement in Legal Theory and in Modern Practice - the Dutch Civil Law Perspective', in K. Boele-Woelki et al. (eds.), International Contract Law 2003. Articles on Various Aspects of Transnational Contract Law (2004) 41, at $56 \mathrm{ff}$.

89. Furmston and Tolhurst, above n. 6 , at 22 and 11-27; Blanchard, above n. 73, at 5; Ph. Le Tourneau (ed.), Droit de la Responsabilité et des Contrats, 9th ed. (2012), at 409

90. Fontaine and De Ly, above n. 80; Lake and Draetta, above n. 87.

91. See above, n. 86. ronment of the transaction. They do not always contain obligations that would be part of the future contract, but deal with the management of negotiations and other issues within the dynamic constituent of the negotiations. However, these documents may also contain some elements of offer and acceptance. Defining to which constituent of negotiation a document or its concrete condition relates allows therefore to distinguish between elements of contract formation and various other documents created in negotiations. This criterion can be applied to other precontractual documents, independently of the name that contracting parties would give them in practice. Any precontractual document, independently of its name, can be related to one of the constituents of negotiation, and a conclusion on the applicability of the doctrine of offer and acceptance thereto can be made.

Concluding on this point, we suggest that in order to find the elements of contract formation in negotiations, the content of the concrete negotiations should be divided into two constituents. Two overlapping constituents should be separated for analysis of this document's content. Thereafter, if a substantive constituent is in place, offer and acceptance or a conduct showing agreement (the issues within the substantive constituent) should be searched for in the documents or conduct related to the substantive constituent.

\subsection{The Moment of Contract Formation:} Situating the 'Point of No Return'

Within the context of negotiations, the exact moment of contract formation is the time at which the parties reach a 'point of no return'92 in the negotiation process and are bound by a contractual obligation. The moment of contract formation is related to the establishment of the existence of contract because if no contract came into existence, it is not possible to define the moment of formation. As has been explained in Section 4.2, the elements of contract formation are to be found within the substantive constituent of negotiation. Consequently, the moment of contract formation is situated as well within the substantive constituent of negotiation and is not related to the agreements and discussions, which are part of the dynamic constituent of negotiations.

To illustrate this point, an example of a negotiation can be envisaged. For example, parties have negotiated a future possible joint production of an innovative product. Their negotiations were developed in an intensive and generally cooperative way. Parties discussed the possible outcome that each of them expects from the joint production, the possible role of each party in the joint production, and exchanged some data on their technical capacities. At the first meeting, parties scheduled the dates of the meetings for the next year and agreed that the contract should be finalised within three years. Thereafter, the negotiators updated each other on the new ideas each month. After one year, a question

92. Kleinheisterkamp, in Vogenauer and Kleinheisterkamp (eds.), above $\mathrm{n}$. 25 , at 218. 
arose whether parties are bound by any contractual commitments. In other words, the question arose whether the 'point of no return' was reached in some way during these negotiations. Analysing this example, the following can be said. The negotiations were cooperative, and the dynamic constituent has been primarily developed (monthly meetings, planning to finalise agreement, the negotiations lasted one year). However, the substantive constituent was much less developed (parties only exchanged ideas on the possible results, but did not commit or agree on any concrete result of negotiations). Since the doctrine assessing the contract formation can only be applied to the issues within the substantive constituent, it is likely that neither an offer or acceptance, nor a conduct showing agreement can be identified in the negotiation of the example. Consequently, the moment of contract formation cannot be identified either. Therefore, the moment of contract formation cannot be found before any agreement on the substantive constituent of negotiations is in place.

This approach to situating the moment of contract formation can be compared with existing views in the legal scholarship regarding the moment when parties may be regarded as bound by a contractual obligation. There are namely three different assumptions about the way negotiations are conducted. The first assumption is rooted in the nineteenth-century civil law theory, which stated that negotiations develop in three progressive steps, and, with each step, the parties become increasingly interdependent. ${ }^{93}$ Becoming interdependent means in this context that parties increasingly rely on each other and their relationship heads only towards the future agreement. This assumption has influenced legal thought in continental Europe. ${ }^{94}$ The second assumption underpins the view of the law of England and Wales and states that parties to negotiations are not interdependent, but are, on the contrary, genuinely adversarial. ${ }^{95}$ Finally, the third assumption states that the behaviour of parties in negotiation is 'chaotic'; it is mentioned by the commentators of the UNIDROIT Principles. ${ }^{96}$ Besides these assumptions, attempts have been made to evaluate the importance of the non-contractual relationship during the formation of contract. For instance, it has been claimed that non-contractual

93. G. Faggella, 'Dei Periodi Precontrattuali e della loro Vera ed Esatta Costruzione Scientifica', in Studi Giuridici in Onore di Carlo Fadda pel XXV Anno del Suo Insegnamento (1906) 269; R. Saleilles, 'De la Responsabilité Contractuelle: A Propos d'une Étude Nouvelle sur la Matière', 6 Revue Trimestrielle de Droit Civil 697 (1907). See also E. Lein and B. Volders, 'Liberté, Loyauté et Convergence: La Responsabilité Précontractuelle en Droit Comparé', in J. Mestre (ed.), Regards Comparatistes sur le Phénomène Contractuel (2009) 17, at 21.

94. Lein and Volders, above n. 93; see, for example, Dutch law in Van Dunné, above n. 85, at 235.

95. Walford v. Miles [1992] 2 AC 128. On this leading case, see inter alia N. Andrews, Contract Law (2011), at 23-30; A. Mills and R. Loveridge, 'The uncertain future of Walford v. Miles' 4 Lloyd's Maritime and Commercial Law Quarterly 528 (2011), at 528 ff.; E. Peel, 'Agreements to Negotiate in Good Faith', in A. Burrows and E. Peel (eds.), Contract Formation and Parties (2010) 37.

96. Kleinheisterkamp, in Vogenauer and Kleinheisterkamp (eds.), above $\mathrm{n}$. 25 , at 218 . relationships are more important in business than contractual relationships. ${ }^{97}$ Scholars supporting the importance of non-contractual relationships in law have argued that a variety of motives other than law regulate the negotiations, formation and execution of contracts. Parties to negotiations can consequently become interdependent because of the non-contractual bounds. According to this view, informal practices and understandings represent an integral part of contractual negotiations and of the contract as well. Other researchers, opposing the importance of the non-contractual relationship in formation of contracts, have argued that contract law plays an important role regulating ex ante the way parties shape long-term relationships. ${ }^{98}$

The view of negotiation studies that we discussed above might nuance these assumptions as well as the disagreement regarding the non-contractual relationship in the formation of contract. Firstly, negotiation is not a chaotic process, but a conscious practice that is organised, managed and has a logical internal structure (as has been discussed in Section 3.2). Secondly, the structure of the dynamic constituent does not correspond to the civil law scholarship assumption regarding the increase of interdependence of the parties during the negotiations. The fact of negotiating during a considerable time and progressing in the details of the discussions does not automatically imply that the parties approach the moment of the contract formation. Thirdly, parties to a possible future contract often reason ex ante in terms of strategy and tactics, ${ }^{99}$ but not in terms of the offer and acceptance doctrine. Finally, discussing the importance of the non-contractual relationship, the issues within the dynamic constituent (i.e. non-contractual relationships) are important for the parties in order to manage the negotiation process. However, their importance is limited to the dynamic constituent of negotiations. The 'point of no return' in the sense of contract formation is also to be sought not in the field of tactics, but within the substantive constituent of negotiation.

\section{Conclusion}

The difficulties in applying the offer and acceptance rules to formation of contract through negotiations are clearly linked to the process whereby parties negotiate modern contracts. Negotiations as a process, therefore, warrants special attention, and the knowledge about

97. This view is often referred to as 'Wisconsin school of law and sociology'. See S. Macaulay, 'Non-Contractual Relations in Business: A Preliminary Study', 28 American Sociological Review 55 (1963) and a followup article S. Macaulay, 'An Empirical View of Contract', 1985 Wisconsin Law Review 465 (1985). For another empirical research on the process of business transactions, see $\mathrm{H}$. Beale and T. Dugdale, 'Contracts between Businessmen: Planning and the Use of Contractual Remedies', 2 British Journal of Law and Society 45 (1975).

98. A. Arrighetti, R. Bachmann \& S. Deakin, 'Contract law, Social Norms and Inter-firm Cooperation', 21 Cambridge Journal of Economics 171 (1997). The finding of these authors differentiates, however, between countries (Germany, Britain and Italy).

99. Kaplan, above n. 46 . 
negotiations, which is available in negotiation studies, should be taken into account by legal theory.

In this article, an attempt has been made to apply the concepts used by negotiation studies to the assessment of the formation of contract by the doctrine of offer and acceptance. This application allows drawing attention to the following points. Firstly, whereas the doctrine of offer and acceptance is designed to assess the issues related to the substance of the future eventual contract (the substantive constituent of negotiations), these issues overlap within the context of negotiations with strategic and tactical behaviour of the negotiators (the dynamic constituent of negotiations). This is why a demarcation between the substantive and the dynamic constituents of negotiations can be used as a criterion for distinguishing between the documents and conduct forming a contract, on the one hand, and other precontractual documents and conduct, on the other hand. Secondly, due to the fact that the elements of contract formation are to be found within the substantive constituent of negotiations, the moment of contract formation is situated as well within the substantive constituent of negotiations and is not related to the agreements and discussions that are part of the dynamic constituent of negotiations. Finally, patterns of conduct described by negotiation studies as integrative and distributive negotiation can serve as criteria for assessing how the path towards a contract has been followed by the parties and which agreements concretely are the contractual conditions. It is our submission therefore that in order to find the elements of contract formation in negotiations, the content of the concrete negotiations should be divided into two constituents. Overlapping constituents should be separated for analysis of this document's content. Thereafter, if a substantive constituent is in place, offer and acceptance or a conduct showing agreement (the issues within the substantive constituent) should be found in the documents or in conduct related to the substantive constituent.

In this way, using concepts from negotiation studies can benefit the adaptation of the application of the doctrine of offer and acceptance to the modern tendency of forming contracts in negotiations. However, such a translation of concepts from negotiation studies into the internal logic of legal doctrinal analysis should not underestimate the difficulties often faced by interdisciplinary research. ${ }^{100}$ For instance, knowledge from other studies should not be oversimplified to avoid dilettantism. In this light, it should be kept in mind that negotiation studies is a field that is currently forming and relies on a combination of different methods. Future developments of this field will show to what extent the concepts and knowledge can be translated into law.

Accordingly, given the fact that negotiation studies is a developing field, relating its outcome to contract theory might also enrich the points of view within negotiation studies, thanks to the rigorousness and detailed elaboration of the concepts within contract theory.

100. See inter alia with further references van Klink and Taekema, above $\mathrm{n}$. 12; van Boom, Giesen \& Verheij, above n. 12. 